\title{
Evaluation of Supplemental Pre-Treatment Development Requirements to Meet TRL 6: Rotary Microfiltration
}

Author Name:

\section{H. J. Huber}

Washington River Protection Solutions, LLC

Richland, WA 99352

U.S. Department of Energy Contract DE-AC27-08RV14800

$\begin{array}{lll}\text { EDT/ECN: } & \text { DRF } & \text { UC: } \\ \text { Cost Center: } & & \text { Charge Code: } \\ \text { B\&R Code: } & & \text { Total Pages: } 27\end{array}$

Key Words: Technology Readiness Level, Supplemental Treatment, Rotary Microfiltration

Abstract: This document evaluates the testing needs for technology maturation of Rotary Microfiltration at Hanford in support of the critical decission 2 package of supplemental pre-treatment.

TRADEMARK DISCLAIMER. Reference herein to any specific commercial product, process, or service by trade name, trademark, manufacturer, or otherwise, does not necessarily constitute or imply its endorsement, recommendation, or favoring by the United States Government or any agency thereof or its contractors or subcontractors.
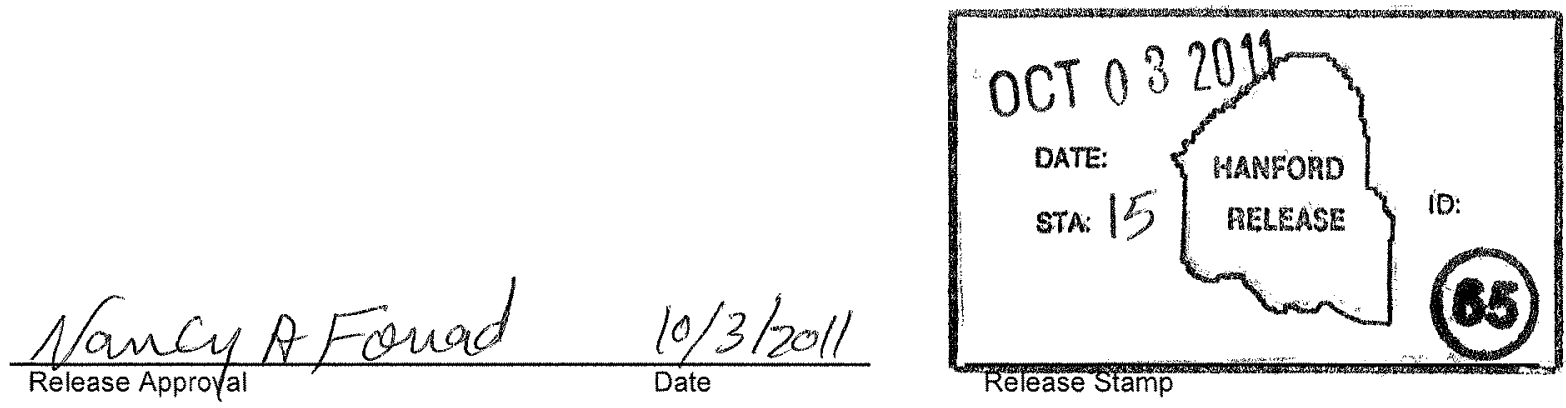

Approved For Public Release 


\title{
Evaluation of Supplemental Pre-Treatment Development Requirements to Meet TRL 6: Rotary Microfiltration.
}

\author{
Authors \\ H. J. Huber \\ Washington River Protection Solutions LLC
}

A. A. Ramsey

AEM Consulting, LLC

Date Published

September 2011

\section{washington river} protectionsolutions

Prepared for the U.S. Department of Energy

Office of River Protection

Contract No. DE-AC27-08RV14800 


\section{EXECUTIVE SUMMARY}

In spring 2011, the Technology Maturation Plan (TMP) for the Supplemental Treatment Project (RPP-PLAN-49827, Rev. 0, Technology Maturation Plan for the Treatment Project (T4SO1) was developed. This plan contains all identified actions required to reach technical maturity for a field-deployable waste feed pretreatment system. The supplemental pretreatment system has a filtration and a Cs-removal component. Subsequent to issuance of the TMP, rotary microfiltration (RMF) has been identified as the prime filtration technology for this application. The prime Cs-removal technology is small column ion exchange (ScIX) using spherical resorcinol formaldehyde (sRF) as the exchange resin. During fiscal year 2011 (FY2011) some of the tasks identified in the TMP have been completed. As of September 2011, the conceptual design package has been submitted to DOE as part of the critical decision (CD-1) process.

This document describes the remaining tasks identified in the TMP to reach technical maturity and evaluates the validity of the proposed tests to fill the gaps as previously identified in the TMP. The potential vulnerabilities are presented and the completed list of criteria for the DOE guide DOE G 413.3-4 different technology readiness levels are added in an attachment. This evaluation has been conducted from a technology development perspective - all programmatic and manufacturing aspects were excluded from this exercise. Compliance with the DOE G 413.3-4 programmatic and manufacturing requirements will be addressed directly by the Treatment Project during the course of engineering design.

The results of this evaluation show that completion of the proposed development tasks in the TMP are sufficient to reach TRL 6 from a technological point of view. The tasks involve actual waste tests using the current baseline configuration $\left(2^{\text {nd }}\right.$ generation disks, 40 psi differential pressure, $30^{\circ} \mathrm{C}$ feed temperature) and three different simulants - the PEP, an AP-Farm and an Ssaltcake. Based on FY2011 dollars used in the TMP, these tests will have ROM costs of $\$ 950 \mathrm{~K}$ and require up to 10 months to complete. Completion of the simulant testing will satisfy the TRL 5 and TRL 6 criteria that are related to system testing with materials that represent the full range of properties in a relevant environment. 


\section{CONTENTS}

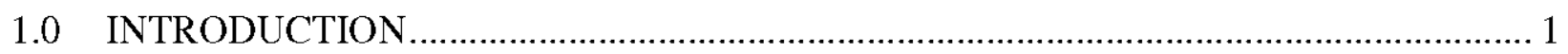

2.0 SUMMARY OF PREVIOUS, PROPOSED AND REQUIRED TESTING ......................... 2

$2.1 \quad$ Rotary Microfiltration Testing (Including 2011) .................................................. 2

2.2 Summary of TRL6 Tasks in Technology Maturation Plan ..................................... 3

2.3 Identified Gaps in the Technology Readiness Criteria............................................ 4

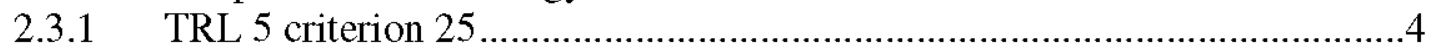

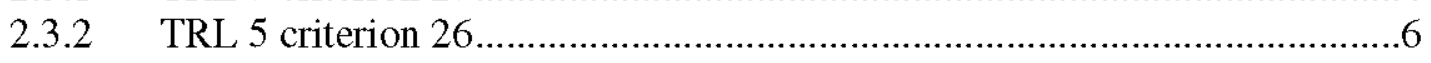

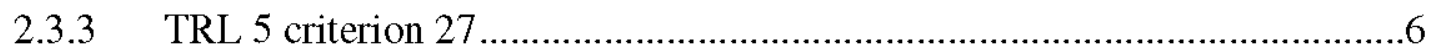

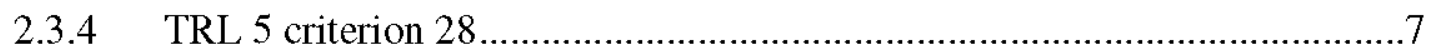

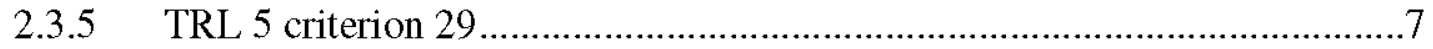

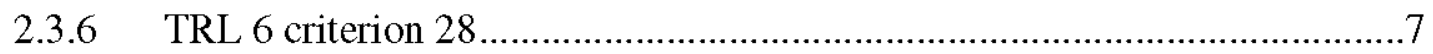

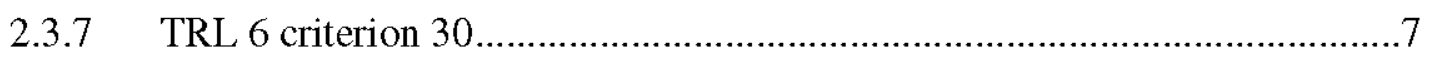

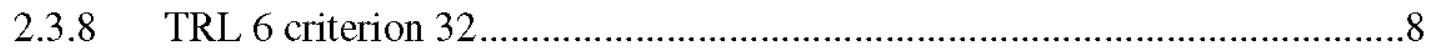

3.0 POTENTIAL VULNERABILITIES AND OPPORTUNITIES …………………........... 8

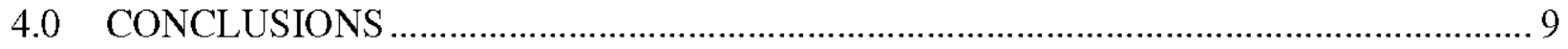

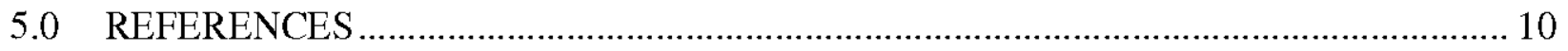

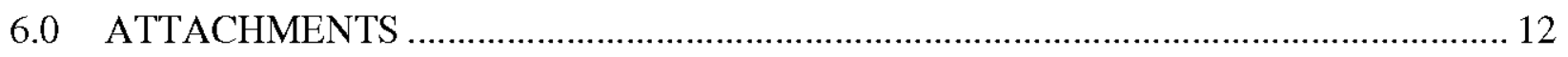

Attachment: Technology Readiness Level Criteria ……................................................ 13

\section{TABLES}

Table 1. Chemical Composition of AN-105, PEP and AP-Feed Supernates.................................5

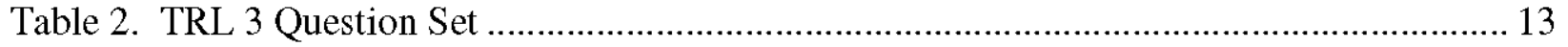

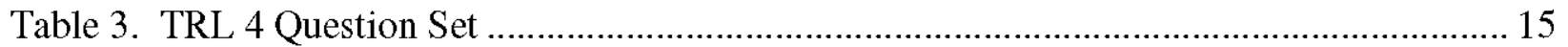

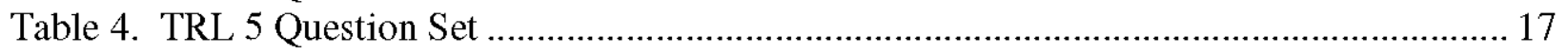

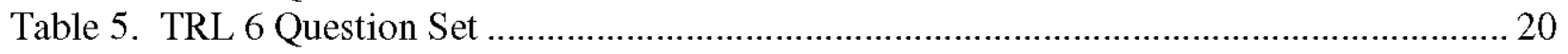




\section{TERMS}

$\begin{array}{ll}\text { Abbreviations and Acronyms } \\ \text { CD } & \text { Critical Decission } \\ \text { CFF } & \text { Cross Flow Filter } \\ \text { CTE } & \text { Critical Technology Element } \\ \text { CUF } & \text { Cross Flow Ultrafiltration } \\ \text { DOE } & \text { Department of Energy } \\ \text { FY } & \text { Fiscal Year } \\ \text { LAW } & \text { Low Activity Waste } \\ \text { PEP } & \text { Pretreatment Engineering Platform } \\ \text { PNNL } & \text { Pacific Northwest National Laboratory } \\ \text { REDOX } & \text { Reduction-Oxidation } \\ \text { RMF } & \text { Rotary Microfilter } \\ \text { ROM } & \text { Rough Order of Magnitude } \\ \text { ScIX } & \text { Small Column Ion Exchange } \\ \text { SOW } & \text { Statement of Work } \\ \text { sRF } & \text { Spherical Resorcinol Formaldehyde } \\ \text { SRNL } & \text { Savannah River National Laboratory } \\ \text { SRS } & \text { Savannah River Site } \\ \text { TMP } & \text { Technology Maturation Plan } \\ \text { TRL } & \text { Technology Readiness Level } \\ \text { WRPS } & \text { Washington River Protection Solutions } \\ \text { WTP } & \text { Waste Treatment and Immobilization Plant } \\ & \end{array}$

\section{Units}

$\begin{array}{ll}\mathrm{M} & \text { Molar } \\ \mu \mathrm{m} & \text { Micrometer } \\ \text { psi } & \text { Pounds per square inch } \\ \text { wt\% } & \text { Weight percent }\end{array}$




\subsection{INTRODUCTION}

The Technology Maturation Plan (TMP) for the Supplemental Treatment Project (RPP-PLAN49827, Rev. 0, Technology Maturation Plan for the Treatment Project (T4S01)) delineates the scope, development activities, schedule and costs required to advance each identified Critical Technology Element (CTE) to at least Technology Readiness Level 6 (TRL 6) as defined by the Department of Energy (DOE) guide DOE G 413.3-4. A TRL 6 rating is required to submit the critical decision (CD)-2 package to DOE. Rotary Microfiltration (RMF) has been identified as a CTE in the supplemental treatment process.

The purpose of the Supplemental Treatment System is to provide an alternate low activity waste (LAW) stream in addition to the Waste Treatment and Immobilization Plant (WTP) Pretreatment Facility. The Supplemental LAW stream could be used as feed for an 'Early LAW' vitrification initiative or Supplemental Immobilization to expedite LAW processing. The Supplemental Pretreatment System contains a filtration unit, the $\mathrm{RMF}^{1}$, and a small column ion exchange (ScIX) cesium removal unit.

The RMF has been developed by SpinTek Filtration ${ }^{\circledR 2}$ and SRNL based on funding by the DOE Office of Environmental Management for the purpose of deployment within the DOE complex. The RMF uses multiple metal filter disks with Pall ${ }^{\circledR} \mathrm{PMM}^{3} 050$ sintered metal media on either surface. The disks are spaced along a hollow central shaft that spins inside a pressurized housing. The differential pressure between the housing and the inside of the disks drives filtrate across the membrane. An external motor rotates the central shaft and disk assembly. The speed of the disk rotation can be adjusted to increase the shear forces at the surface of the disks. The shear force disrupts particulate deposition thus minimizing filter cake build-up on the filter surfaces. Stationary spoke turbulence promoters are positioned above and below each disk, which also increases the shear rate at the surface of the membrane.

The original unit from the vendor was not field-deployable in a radiation environment. During the last decade, testing and development was completed on single disk units with simulants and actual waste, pilot scale units (3-disk) and full-scale units (25-disk). The design was completely overhauled by SRNL to provide a unit that can be used in the field either within a riser or in a tank pit. The most recent suite of tests included a tandem unit with two computer controlled fullscale units in a mock-up tank riser deployment.

The TMP outlines a very aggressive cost and schedule plan. Twelve RMF-related development tasks were identified in the TMP to mature the technology in support of the Supplemental Treatment Project. These twelve activities are described in detail in Section 2.2. Since its issuance in June 2011, significant changes in anticipated funding profiles and deployment strategies have delayed testing activities and development accomplishments. As of September 30, 2011, i.e., year end FY2011, the most significant variations from the TMP are as follows:

\footnotetext{
${ }^{1}$ In the recently prepared conceptual design report (RPP-RPT-50024, Treatment Project T4S01 Conceptual Design Report.) cross flow filtration is identified as a viable alternative in case the technology development of RMF does not progress sufficiently.

${ }^{2}$ SpinTek is a registered trademark of SpinTekfiltration, Los Alamitos, California.

${ }^{3}$ Pall and PMM are registered trademarks of Pall Corporation, Port Washington, New York.
} 
- Within the FY2011 tasks for RMF testing, RMF 1 and 2 could not be performed. These tests covered the 25-disk unit testing and the 3-disk unit testing with Pretreatment Engineering Platform (PEP) ${ }^{4}$ simulant at the Savannah River National Laboratory (SRNL) and at the SpinTek facility.

- RMF task 4 (Development of two simulants for tandem unit testing based on PNNL recipes) is partially impacted as only the S-farm simulant recipe was finished in FY2011. The AP-Farm simulant recipe will be finished in FY2012 and is based on the proposed composition in RPP-RPT-50764, Rev. 0, Evaluation of AP-Farm Simulant Composition for Rotary Microfilter Testing.

The re-evaluation of the TRL-levels strictly adheres to the question sets and protocols defined in DOE G 413.3-4. The TMP was developed to be in alignment with RPP-RPT-48092, Supplemental Treatment Project Technology Readiness Assessment, which used a slightly different question set as its basis. The re-evaluation included all recently published documents up to September 2011. The result is still a TRL of 4 with several criteria unfulfilled at TRL5 and TRL6. This is not surprising, since no major testing effort could be finished in FY2011.

\subsection{SUMMARY OF PREVIOUS, PROPOSED AND REQUIRED TESTING}

The complete DOE G413.3-4 questionnaire associated with TRL 3 through TRL 6 is provided, and each individual question addressed, in the Attachment to this document. Each criterion was evaluated against results in publically released reports, including those mentioned in chapter 2.1, and the individual publications of relevance are cited in response to the questions. For those instances where the available test data / information are insufficient, an " $\mathrm{N}$ " was set in the "Y/N" column. The criteria with an "N" are addressed in the body of the document in Section 2.3 and compared to the development activities proposed in the TMP (see chapter 2.2).

\subsection{ROTARY MICROFILTRATION TESTING (INCLUDING 2011)}

This section covers test reports that were released after the RMF compilation document (RPP-RPT-49753, Rev. 0, Compendium of Completed Testing in Support of Rotary Microfiltration at Savannah River Site and Hanford) was issued. The tests were initiated and mostly performed by SRNL and primarily supported the SRS deployment of an RMF-ScIX system. However, the results and lessons learned from these tests are valuable guidance for future Hanford-related tests.

- Fowley M. D. and Herman D. T., Backpressure Testing of Rotary Microfilter Disks (U), SRNL-STI-2010-00790, Rev. 0, April 2011: This test series identified the maximum backpressure a baseline disk can withstand and the effects of such backpressure on disk performance. Back pressure of up to 75 psi was applied to two disks with post-forward pressure to identify the permanent deformation of the membranes. The membranes did not tear or burst, however, permanent deformation was induced starting at 5 psi backpressure.

\footnotetext{
${ }^{4}$ The Pretreatment Engineering Platform was a pilot test facility for WTP. The simulant composition used during PEP testing is also being tested with the RMF.
} 
In one case the disk warped so badly that it would have scraped along the promoters during operation.

- Herman D. T., Development of a Laminated Disk for the SpinTek Rotary Microfilter, SRNLSTI-2011-00279, Rev. 0, May 2011: This report summarizes the development of different filter disk designs. The baseline disks with the wire mesh separator and the fully-sintered, laminated disks were described. In particular, the laminated disk test results are presented in this report. A $5 \mathrm{wt} \%$ strontium carbonate slurry was filtered with a filtrate flux about 2-3x greater than the filtrate flux of the baseline disks. The backflow permeate flow rate was comparable to the forward flow rate; however, this particular test run used only deionized water. The laminated disks have the potential to increase feed throughput and to use backflowing as a cleaning method (rather than acid cleaning).

- Herman D. T., Fowley M. D., and Stefanko D. B., Testing of the Dual Rotary Filter System, SRNL-STI-2011-00466, Rev. 0, August 2011: SRNL installed and tested a system of two hydraulically connected SpinTek RMF units. This was the first time the tandem configuration was tested; previous testing used single 25-disk units. To provide sufficient feed to an immobilization system, parallel arrangements of up to 8 units are planned for the Hanford pretreatment system. For the test runs the feed was water, a salt simulant and a simulated sludge. The tests were focused on the control software and on the hydraulic behavior of two parallel filters feeding a ScIX column. The operation personnel learned highly valuable lessons on handling and maintaining the filter units.

\subsection{SUMMARY OF TRL6 TASKS IN TECHNOLOGY MATURATION PLAN}

In a preliminary technology readiness assessment (RPP-RPT-48092, Rev. 0, Supplemental Treatment Program Technology Readiness Assessment) the TRL level for RMF was determined to be TRL 4 for Hanford applications (i.e., completed "component and/or system validation in laboratory environment"). Although several criteria required for TRL 5 and 6 were already fulfilled, the lack of design application concepts and functional requirements and testing of a representative range of Hanford-specific actual waste samples and simulants reduced the TRL to 4. The remaining development tasks required to mature the technology up to TRL8 (cold commissioning phase) were identified in the TMP.

The tests/activities required to achieve TRL 6 are:

RMF-1: Test PEP simulant in 25 baseline disk unit. The PEP simulant was prepared in FY2011, testing is postponed to FY2012.

RMF-2: Test PEP simulant in 3-disk unit with laminated and baseline disks. The results will allow scale-up verification and determination of improvement in filtrate flux for laminated disks over baseline model using a Hanford-related simulant.

RMF-3: DQO process to identify average initial feed composition. This task is finished and the report (RPP-RPT-50764, Rev. 0) was released on September 19, 2011.

RMF-4: Preparation of two simulants for SRNL testing based on PNNL recipe. In FY2011, PNNL was tasked to provide a Statement of Work (SOW) with the recipes for a saltcake simulant and an AP-farm simulant. This SOW will be used to prepare the simulants in small batches by SRNL and outsource the production. 
RMF-5a: Performance testing over a range of simulants using SRNL tandem unit at baseline conditions ( $40 \mathrm{psi}$ differential pressure, $30^{\circ} \mathrm{C}$ feed temperature) with $0.5 \mu \mathrm{m}$ filter medium. The simulants include the PEP, AP farm, and saltcake simulant. Solids loadings will be at $0.5,5 \&$ $10 \mathrm{wt} \%$ solids. Each test is run for 100 hours with added solids after $1 / 3$ and $2 / 3$ of the test duration.

RMF-5b, 7 to 9 and 11: these tasks were identified to be non-essential for TRL 6 but a need-tohave for TRL 6+; they are not evaluated within this document.

RMF-6: 1000-hour test with AP Farm simulant in the 25-disk unit at SRNL. This endurance test will provide stress test data to help estimate maintenance requirements and long-term filtration performance using a deployment-specific simulant. This test is not specifically addressed in the TRL criteria, however it deemed essential for planning purposes.

RMF-10: Performance testing with AN-105 tank waste equipped with baseline disks. This task will be performed at 222-S using the currently available unit.

RMF-12: Cost-benefit analysis on laminated (backflow) disks. Based on already published data and data from task RMF-2, the benefit of increased filtrate flux and modified cleaning protocols will be evaluated.

\subsection{IDENTIFIED GAPS IN THE TECHNOLOGY READINESS CRITERIA}

The list of criteria below is excerpted from the TRL evaluation in the Attachment and is drawn directly from DOE G413.3-4. Only criteria with missing information are discussed in this Section. The basic approach is to identify whether or not the proposed tasks in the TMP are sufficient to provide the technology-specific basis for a successful submittal of the CD-2 package.

\subsubsection{TRL 5 criterion 25}

\begin{tabular}{|l|l|}
\hline $\begin{array}{l}\text { Simulants have been } \\
\text { developed that } \\
\text { cover the full range } \\
\text { of waste properties }\end{array}$ & $\begin{array}{l}\text { WSRC-TR-2000-00338, Hanford Waste Simulant created to Support } \\
\text { Research and Development on the River Protection Project - Waste } \\
\text { Treatment Plant. } \\
\text { RPP-RPT-50764, Evaluation of AP-Farm Simulant Composition for } \\
\text { Rotary Microfilter Testing. } \\
\text { Task RMF-4 RPP-PLAN-49827, Technology Maturation Plan for the } \\
\text { Treatment Project (T4S01): Preparation of two simulants for SRNL } \\
\text { testing based on PNNL recipe. }\end{array}$ \\
\hline
\end{tabular}

To date the AN-105 simulant is the only Hanford-related simulant that has been tested on pilotor full-scale units. The first document, WSRC-TR-2000-00338, covers the development of the AN-105 simulant. This simulant was chosen by SRNL for initial Hanford related testing due to its availability in large quantities from previous testing on technology development tasks. It is considered an average Hanford simulant, since it is based on the so-called Envelope A which covers most of Hanford's tank waste.

The PEP simulant was prepared for testing of the filtration function within the WTP Pretreatment Facility. The filtration unit was a cross flow filter (CFF) and a wide range of filtration test data 
was obtained. In order to appropriately compare the two filtration technologies cross-flow Ultrafiltration (CUF) and RMF, the PEP simulant was chosen to be tested in the full-scale unit and in the pilot scale unit with baseline and laminated disks (see 2.3.3, TRL5 criterion 27).

Since neither AN-105 nor the PEP simulant are directly representative of the anticipated supplemental pretreatment feed, a simulant needed to be identified that was directly relevant in order to identify the filtration capacity needs for the system. In RPP-RPT-50764, the composition and rationale for the AP-farm simulant are described. As can be seen in Table 1, the three different simulant supernates span a wide range of the main constituents: aluminum, sodium, hydroxide, nitrate and nitrite. Oxalate and phosphate variations are specifically important with respect to solids formation during testing - any concentration runs will cause some of these salts to precipitate; their needle shaped crystalline structures are especially challenging filtration materials.

Table 1. Chemical Composition of AN-105, PEP and AP-Feed Supernates.

\begin{tabular}{|l|c|c|c|}
\hline \multicolumn{1}{|c|}{$[\mathbf{M}]^{\mathbf{5}}$} & AN-105 & PEP & AP-Feed \\
\hline Aluminum & 0.69 & 0.12 & 0.56 \\
Potassium & 0.09 & 0.00 & 0.14 \\
Sodium & 5.00 & 5.00 & 7.20 \\
Nitrite & 1.13 & 0.51 & 1.53 \\
Nitrate & 1.25 & 1.60 & 2.31 \\
Phosphate & 0.003 & 0.07 & 0.07 \\
Sulfate & 0.004 & 0.18 & 0.08 \\
Oxalate & 0.003 & 0.01 & 0.02 \\
Chloride & 0.12 & 0.00 & 0.11 \\
Hydroxide & 1.61 & 1.59 & 1.46 \\
TOC & 0.08 & 0.03 & 0.23 \\
TIC & 0.10 & 0.55 & 0.68 \\
\hline
\end{tabular}

The fourth simulant, an S-Saltcake composite simulant will be based on an actual REDOX composite used in prior PNNL filtration and leaching testing (PNNL-17965, WTP-RPT-172, Rev. 0, Filtration and Leach Testing for REDOX Sludge and S-Saltcake Actual Waste Sample Composites). Historically the S-saltcake caused the lowest filtrate rates in CUF and RMF tests (see PNNL-17965 and LAB-RPT-10-00002, Rev. 0, Testing of the SpinTek Rotary Microfilter using Actual Hanford Waste Samples.). The simulant recipe was prepared in FY2011, with the large batch to be prepared as part of Task RMF-4 in FY2012.

All four simulants were/will be prepared with separated undissolved solids and supernate. This possibility for adjustable amounts of undissolved solids in the test slurries, in combination with the differences in supernate chemistry (i.e., viscosity at a given temperature), covers a sufficiently wide range of filtration conditions to satisfy the criterion.

\footnotetext{
${ }^{5}$ AN-105 data based on WSRC-STI-2008-00339, Rev. 0, Table 1; PEP simulant based on WTP-RPT-204, Rev. 0, Attachment A; AP-Feed based on RPP-RPT-50764, Rev. 0, Table 1 "Unadjusted Feed".
} 


\subsubsection{TRL 5 criterion 26}

\begin{tabular}{|l|l|}
\hline $\begin{array}{l}\text { Testing has verified } \\
\text { that the properties/ } \\
\text { performance of the } \\
\text { simulants match the } \\
\text { properties/performance } \\
\text { of the actual wastes }\end{array}$ & $\begin{array}{l}\text { WSRC-TR-2004-00213, Pilot-Scale Testing of a SpinTek Rotary } \\
\text { Microfilter with Welded Disks and Simulated Savannah River Site } \\
\text { High Level Waste. }\end{array}$ \\
WSRC-TR-2003-00030, Testing of the SpinTek Rotary Microfilter \\
using Actual Waste. \\
WRPS-0802568, Report on SpinTek Rotary Microfilter Feed \\
Sample Comparison. \\
\\
$\begin{array}{l}\text { LAB-RPT-10-00002, Testing of the SpinTek Rotary Microfilter } \\
\text { using Actual Hanford Waste Samples. } \\
\text { Task RMF-10 RPP-PLAN-49827, Technology Maturation Plan } \\
\text { for the Treatment Project } \text { (T4S01): Performance testing with AN- } \\
\text { 105 tank waste with baseline disks. }\end{array}$ \\
\hline
\end{tabular}

The comparison of the actual and simulant waste chemical and mineralogical properties was reported in WRPS-0802568. The performance of the actual and simulant samples is not yet entirely identified. In general, a reduction in filtrate flux of $20-35 \%$ for actual waste compared to the equivalent simulants can be observed. The performance changes within the individual slurries are matching - increases in solids content reduce filtrate fluxes for actual and simulant waste. AN-105 produces a higher filtrate flux than the S-saltcake.

However, in the first comparative study, reported in LAB-RPT-10-00002, two disks of the first generation disk set were used. The results were rather ambiguous: the filtrate flux varied by 100 to $200 \%$ between the two $0.5 \mu \mathrm{m}$ disks. Since the second generation (baseline) disks have shown much more reproducible and distinctly higher filtrate fluxes in simulant tests, these disks need to be tested with the $\mathrm{AN}-105$ actual waste sample for a definitive answer.

\subsubsection{TRL 5 criterion 27}

\begin{tabular}{|l|l|}
\hline $\begin{array}{l}\text { Laboratory-scale } \\
\text { tests on the full } \\
\text { range of simulants } \\
\text { using a prototypical } \\
\text { system have been } \\
\text { completed }\end{array}$ & $\begin{array}{l}\text { WSRC-STI-2008-00339, Testing of a Rotary Microfilter to Support } \\
\text { RPP-RPT-40897, Testing of the SpinTek Rotary Microfilter using } \\
\text { Simulated Hanford Waste Samples. }\end{array}$ \\
& $\begin{array}{l}\text { Task RMF-2 RPP-PLAN-49827, Technology Maturation Plan for } \\
\text { the Treatment Project (T4S01): Test PEP simulant in 3-disk unit with } \\
\text { laminated and baseline disks. } \\
\text { Task RMF-5a RPP-PLAN-49827, Technology Maturation Plan for } \\
\text { the Treatment Project (T4S01): Performance testing over a range of } \\
\text { simulants using SRNL tandem unit at baseline conditions. }\end{array}$ \\
\hline
\end{tabular}

To date, only the AN-105 simulant was tested at SRNL and 222-S. The planned simulant tests include the PEP, AP-Farm and an S-Saltcake simulant (see 2.3.1.) in a matrix of performance tests and will cover the required range of testing. 


\subsubsection{TRL 5 criterion 28}

\begin{tabular}{|l|l|}
\hline $\begin{array}{l}\text { Laboratory-scale } \\
\text { tests on a limited } \\
\text { range of real wastes } \\
\text { using a prototypical } \\
\text { system have been } \\
\text { completed }\end{array}$ & $\begin{array}{l}\text { LAB-RPT-10-00002, Testing of the SpinTek Rotary Microfilter using } \\
\text { Actual Hanford Waste Samples. }\end{array}$ \\
Task RMF-10 RPP-PLAN-49827, Technology Maturation Plan for \\
the Treatment Project (T4SO1): Performance testing with AN-105 \\
tank waste with baseline disks.
\end{tabular}

LAB-RPT-10-00002 reports tests on two actual waste samples. These two actual waste samples cover (1) the "average Hanford" case of a double shell tank that was used as the basis for Envelope A and (2) a dissolved saltcake from a single shell tank. The remaining task is to verify the increased filtrate flux of the $2^{\text {nd }}$ generation disk (i.e., baseline disk) on $\mathrm{AN}-105$ waste.

\subsubsection{TRL 5 criterion 29}

\begin{tabular}{|l|l|}
\hline $\begin{array}{l}\text { Test results for } \\
\text { simulants and real } \\
\text { waste are consistent }\end{array}$ & $\begin{array}{l}\text { WSRC-TR-2003-00030, Testing of the Spintek Rotary Microfilter } \\
\text { using Actual Waste. } \\
\text { LAB-RPT-10-00002, Testing of the SpinTek Rotary Microfilter using } \\
\text { Actual Hanford Waste Samples. } \\
\text { Task RMF-10 RPP-PLAN-49827, Technology Maturation Plan for } \\
\text { the Treatment Project (T4S01): Performance testing with AN-105 } \\
\text { tank waste with baseline disks. }\end{array}$ \\
\hline
\end{tabular}

After completion of the actual waste tests with a $2^{\text {nd }}$ generation disk (i.e., baseline disk), the results can be compared and finally evaluated. As mentioned in 2.3.2, the two real waste samples and equivalent simulants have matching characteristics and filtration behavior.

\subsubsection{TRL 6 criterion 28}

\begin{tabular}{|l|l|}
\hline $\begin{array}{l}\text { Engineering-scale } \\
\text { tests on the full } \\
\text { range of simulants } \\
\text { using a prototypical } \\
\text { system have been } \\
\text { completed. }\end{array}$ & $\begin{array}{l}\text { WSRC-STI-2008-00339, Testing of a Rotary Microfilter to Support } \\
\text { Tanford Applications. } \\
\text { the Treatment Project (T4SO1): Performance testing over a range of } \\
\text { simulants using SRNL tandem unit at baseline conditions. }\end{array}$ \\
\hline
\end{tabular}

After completion of task RMF-5a the range of simulants (see comment in 2.3.1) will be tested.

\subsubsection{TRL 6 criterion 30}

\begin{tabular}{|l|l|}
\hline $\begin{array}{l}\text { Laboratory and } \\
\text { engineering-scale }\end{array}$ & $\begin{array}{l}\text { WSRC-STI-2008-00339, Testing of a Rotary Microfilter to Support } \\
\text { Hanford Applications. }\end{array}$
\end{tabular}




\begin{tabular}{|c|c|}
\hline $\begin{array}{l}\text { experiments are } \\
\text { consistent }\end{array}$ & $\begin{array}{l}\text { RPP-RPT-40897, Testing of the SpinTek Rotary Microfilter using } \\
\text { Simulated Hanford Waste Samples. } \\
\text { Task RMF-1 RPP-PLAN-49827, Technology Maturation Plan for the } \\
\text { Treatment Project (T4S01): Test PEP simulant in 25-disk unit. } \\
\text { Task RMF-2 RPP-PLAN-49827, Technology Maturation Plan for the } \\
\text { Treatment Project (T4S01): Test PEP simulant in 3-disk unit with } \\
\text { laminated and baseline disks. }\end{array}$ \\
\hline
\end{tabular}

To date, the only comparison can be drawn between a single disk unit with $1^{\text {st }}$ generation disk and a single 25 -disk unit with $1^{\text {st }}$ generation disks. Although these tests were highly informative at the time of testing, the results are of no use for the TRL 6 evaluation. Completion of tasks RMF 1 and RMF 2 will provide the necessary data on $2^{\text {nd }}$ generation (baseline) disks for 3 - and 25-disk units.

\subsubsection{TRL 6 criterion 32}

\begin{tabular}{|l|l|}
\hline $\begin{array}{l}\text { Plan for } \\
\text { engineering-scale } \\
\text { testing executed - } \\
\text { results validate } \\
\text { design }\end{array}$ & $\begin{array}{l}\text { WSRC-STI-2008-00339, Testing of a Rotary Microfilter to Support } \\
\text { Hanford Applications. }\end{array}$ \\
SRNL-STI-2011-00466, Testing of the Dual Rotary Filter System. \\
Task RMF-5a RPP-PLAN-49827, Technology Maturation Plan for \\
$\begin{array}{l}\text { the Treatment Project (T4S01): Performance testing over a range of } \\
\text { simulants using SRNL tandem unit at baseline conditions. }\end{array}$
\end{tabular}

The 2011 report on tests with the dual filter system has shown that the design is appropriate for the task. However, the different characteristics of the range of simulants will provide the necessary additional insight to the filter performance.

\subsection{POTENTIAL VULNERABILITIES AND OPPORTUNITIES}

The RMF technology was identified within the TMP at a TRL 4 from a technology perspective. At that time, several activities were identified that are required to advance RMF to a TRL 6 from a technology perspective. These activities are listed in Section 2.2. The approach on filling the identified gaps as outlined in Section 2.3 is based upon several assumptions:

- Funding will be provided and will be sufficient to perform the tasks to support project schedules.

- The engineering and personnel resources will be available. In particular, the tandem unit at SRNL will be available and ready, and the single disk unit at 222-S will be ready.

- The simulants will be prepared on time. 
The ROM costs identified in the TMP were based on successful completion of the FY2011 tasks. Since several of these activities could not be finished due to fluctuations in the funding scenarios and/or delays in the deliverables which fed into some of the tasks, these need to be added to the FY2012 funding. As opposed to the ROM of $\$ 826 \mathrm{~K}$ an estimate of $\$ 950 \mathrm{~K}$ should cover the activities proposed in this evaluation. However, these numbers are estimates on the lower end and are based on FY2011 dollars. A major assumption is that the changes in personnel across the DOE complex and idling of critical equipment will not cause an increase in costs and delay in schedules.

The FY2011 testing of the tandem unit at SRNL has added the option of performing tests at constant filtrate flux rather than constant differential pressure. This was either not possible in prior test setups or highly labor-intensive. While tests at constant differential pressure are necessary to understand the speed and cause of fouling of the filtration unit, a constant filtrate flux is essential for direct feed into an ScIX column. Performing at least some of the test runs in FY2012 at constant filtrate flux would be highly beneficial for engineering planning activities.

The TMP evaluated the CTEs individually. Filtration and cesium removal were examined separately, each as its own integrated component. There was an inherent assumption that the maturation of each CTE to a TRL 6 would generate the components required to demonstrate an integrated system. The interfaces from one CTE to another were not considered. RMF is a mechanical system that functions to provide filtered supernate feed to a small column ion exchange system. Because it is a mechanical system, with a measurable acceptable output, it is reasonable to assume that the interface between CTEs is not a concern. However, during demonstration of the technology, (post TRL6) it is advisable to perform integrated system testing that verifies the performance of the treatment technologies, i.e. RMF and ScIX, as a single CTE.

\subsection{CONCLUSIONS}

The methodology used to evaluate RMF technology maturity in the TMP is valid. From the authors' point of view, identified activities are sufficient to advance the RMF CTE to a TRL 6 from a technology perspective.

Added enhancements to the RMF technology in the form of improved filter media (laminated disks) and a tandem configuration to stabilize flow rate, are not required to mature the technology; however, they would significantly improve efficiency and throughput of the system thus impacting the preliminary design.

It may be advisable during the technology demonstration phase of RMF (post TRL6) to perform integrated system testing that verifies the performance of the treatment technologies, i.e. RMF and ScIX, as a single CTE. 


\subsection{REFERENCES}

Greene W.A., Kirk P. A., Hayes R., Riley J.; Centrifugal Membrane Filtration, Final Report, Contract No. DE-AC21-96MC3313, 1999, SpinTek Membrane Systems, Inc., Huntington Beach, CA.

LAB-RPT-10-00002, Testing of the SpinTek Rotary Microfilter using Actual Hanford Waste Samples, Rev. 0, Washington River Protection Solutions LLC, Richland, WA.

PNNL-17965, Filtration and Leach Testing for REDOX Sludge and S-Saltcake Actual Waste Sample Composites, Rev. 0, Pacific Northwest National Laboratory, Richland, WA.

PNNL-18678, WTP-RPT-204, Scale-up, Production, and Procurement of PEP Simulants, Rev. 0 , Pacific Northwest National Laboratory, Richland, WA.

RPP-46811, Functions and Requirements Analysis: 200-Area Supplemental Treatment and Immobilization System, Rev. 1, Washington River Protection Solutions LLC, Richland, WA.

RPP-47251, Supplemental Treatment Pre-Conceptual System Safety Design Strategy, Rev. 0, Washington River Protection Solutions LLC, Richland, WA.

RPP-50169, Treatment Project T4S01 Conceptual Safety Design Report, Rev. 0, Washington River Protection Solutions LLC, Richland, WA.

RPP-50359, Treatment Project T4S01 Safety Design Strategy, Rev. 0, Washington River Protection Solutions LLC, Richland, WA.

RPP-PLAN-35933, Test Plan for Rotary Microfilter Testing with Simulated and Actual Tank Waste, Rev. 1, Washington River Protection Solutions LLC, Richland, WA.

RPP-PLAN-49827, Technology Maturation Plan for the Treatment Project (T4S01), Rev. 0, Washington River Protection Solutions LLC, Richland, WA.

RPP-RPT-40897, Testing of the SpinTek Rotary Microfilter using Simulated Hanford Waste Samples, Rev. 0, Washington River Protection Solutions LLC, Richland, WA.

RPP-RPT-48092, 2010, Supplemental Treatment Project Technology Readiness Assessment, Rev. 0, Washington River Protection Solutions, LLC, Richland, Washington.

RPP-RPT-48117, Supplemental Treatment Technical Support Pre-Conceptual Candidate Technical Descriptions, Rev. 0, Washington River Protection Solutions LLC, Richland, WA.

RPP-RPT-50024, Treatment Project T4S01 Conceptual Design Report, Rev. 0, Washington River Protection Solutions LLC, Richland, WA.

RPP-RPT-50764, Evaluation of AP-Farm Simulant Composition for Rotary Microfilter Testing, Rev. 0, Washington River Protection Solutions LLC, Richland, WA.

Serra A. C. and Wiesner M. R., A Comparison of Rotating and Stationary Membrane Disk Filters using Computational Fluid Dynamics, 2000, Journal of Membrane Science 165, 19-29.

SRNL-STI-2009-00183, Testing of a full-scale Rotary Microfilter for the Enhanced Process for Radionuclides Removal, Rev. 0, Savannah River National Laboratory, Aiken, SC. 
SRNL-STI-2010-00790, Backpressure Testing of Rotary Microfilter Disks (U), Rev. 0, Savannah River National Laboratory, Aiken, SC.

SRNL-STI-2011-00279, Development of a Laminated Disk for the SpinTek Rotary Microfilter, Rev. 0, Savannah River National Laboratory, Aiken, SC.

SRNL-STI-2011-00466, Testing of the Dual Rotary Filter System, Rev. 0, Savannah River National Laboratory, Aiken, SC.

Stepan D. J., Stevens B. G., Hetland M. D.; EM Task 9 - Centrifugal Membrane Filtration. Final Report, 1999, 99-EERC-10-02, Energy \& Environmental Research Center, University of North Dakota, Grand Forks, ND.

Viadero R. C. Jr., Vaughan R. L. Jr., Reed B. E., Study of Series Resistances in High-Shear Rotary Ultrafiltration, 1999, Journal of Membrane Science 162, 199-211.

WRPS-0802568, Report on SpinTek Rotary Microfilter Feed Sample Comparison, Rev. 0, Washington River Protection Solutions LLC, Richland, WA.

WSRC-RP--90-1145, Alternative Filtration Testing Program: Pre-Evaluation of Test Results $(U)$, Rev. 0, Westinghouse Savannah River Company, Aiken, SC.

WSRC-STI-2006-00073, Testing and Evaluation of the Modified Design of the 25-Disk Rotary Microfilter, Rev. 0, Savannah River National Laboratory, Aiken, SC.

WSRC-STI-2008-00339, Testing of a Rotary Microfilter to Support Hanford Applications.

WSRC-TR-2000-00338, Hanford Waste Simulant created to Support Research and Development on the River Protection Project - Waste Treatment Plant, Rev. 0, Westinghouse Savannah River Company, Aiken, SC.

WSRC-TR-2001-00214, Filtration Systems, Inc., Report for WSRC SpinTek Rotary Microfilter Testing, Rev. 1, Westinghouse Savannah River Company, Aiken, SC.

WSRC-TR-2003-00030, Testing of the SpinTek Rotary Microfilter using Actual Waste, Rev. 0, Westinghouse Savannah River Company, Aiken, SC.

WSRC-TR-2003-00071, Pilot-Scale Testing of a SpinTek Rotary Microfilter with SRS Simulated High Level Waste, Rev. 0, Westinghouse Savannah River Company, Aiken, SC.

WSRC-TR-2004-00213, Pilot-Scale Testing of a SpinTek Rotary Microfilter with Welded Disks and Simulated Savannah River Site High Level Waste, Rev. 0, Westinghouse Savannah River Company, Aiken, SC. 
RPP-RPT-50832

Revision 0

\subsection{ATTACHMENTS}

Contains 1 Attachment, 10 pages 


\section{ATTACHMENT: TECHNOLOGY READINESS LEVEL CRITERIA}

The following tables are drawn from DOE G 413.3-4. The Technology Readiness Level 3 is consistent with a definition of feasibility research. It is described in the DOE TRA Guide as,

"Active research and development is initiated. This includes analytical studies and laboratory scale studies to physically validate the analytical predictions of separate elements of the technology. Examples include components that are not yet integrated or representative. Components may be tested with simulants."

All questions within the TRL 3 question set provided in Table 2, must be answered "yes' to be assigned a TRL 3 designation. The questions encompass technical, programmatic and manufacturing aspects of the evaluated critical technology element. Only technology aspects are shown; the numbering of criteria is unchanged from DOE G 413.3-4.

Table 2. TRL 3 Question Set

\begin{tabular}{|c|c|c|}
\hline $\mathbf{Y} / \mathbf{N}$ & $\begin{array}{l}\text { Criteria (only those related to "Technology, } \\
\text { technical aspects" in DOE G 413.3-4) }\end{array}$ & Basis and Supporting Documentation \\
\hline $\mathrm{Y}$ & 1. Academic (basic science) environment & $\begin{array}{l}\text { Stepan et al (1999), EM-Task 9-Centrifugal Membrane } \\
\text { Filtration Final Report, DE-FC21-94MC31388-30. } \\
\text { WSRC-RP-90--1145, Alternative Filtration Testing } \\
\text { Program: Pre-Evaluation of Test Results }(U) . \\
\text { Greene et al (1999), Centrifugal Membrane Filtration } \\
\text { Final Report, DE-AC21-96MC33136. }\end{array}$ \\
\hline Y & $\begin{array}{l}\text { 3. Predictions of elements of technology } \\
\text { capability validated by analytical studies }\end{array}$ & $\begin{array}{l}\text { WSRC-TR-2001-00214, Filtration Systems, Inc., Report } \\
\text { for WSRC SpinTek Rotary Microfilter Testing. } \\
\text { WSRC-TR-2003-00071, Pilot-Scale Testing of a SpinTek } \\
\text { Rotary Microfilter with SRS Simulated High Level Waste. }\end{array}$ \\
\hline Y & $\begin{array}{l}\text { 5. Science known to extent that } \\
\text { mathematical and/or computer models and } \\
\text { simulations are possible }\end{array}$ & $\begin{array}{l}\text { Viadero et al, (1999), Study of Series Resistances in High- } \\
\text { Shear Rotary Ultrafiltration. } \\
\text { Serra and Wiesner ( } 2000), \text { A Comparison of Rotating and } \\
\text { Stationary Membrane Disk Filters using Computational } \\
\text { Fluid Dynamics. }\end{array}$ \\
\hline $\mathrm{Y}$ & $\begin{array}{l}\text { 7. Predictions of elements of technology } \\
\text { capability validated by Modeling and } \\
\text { Simulation (M\&S) }\end{array}$ & $\begin{array}{l}\text { Serra and Wiesner (2000), A Comparison of Rotating and } \\
\text { Stationary Membrane Disk Filters using Computational } \\
\text { Fluid Dynamics. }\end{array}$ \\
\hline $\mathrm{Y}$ & $\begin{array}{l}\text { 9. Laboratory experiments verify feasibility of } \\
\text { application }\end{array}$ & $\begin{array}{l}\text { WSRC-TR-2003-00071, Pilot-Scale Testing of a SpinTek } \\
\text { Rotary Microfilter with SRS Simulated High Level Waste. } \\
\text { WSRC-TR-2004-00213, Pilot-Scale Testing of a SpinTek } \\
\text { Rotary Microfilter with Welded Disks and Simulated } \\
\text { Savannah River Site High Level Waste. }\end{array}$ \\
\hline $\mathrm{Y}$ & $\begin{array}{l}\text { 10. Predictions of elements of technology } \\
\text { capability validated by laboratory experiments }\end{array}$ & $\begin{array}{l}\text { WSRC-TR-2003-00071, Pilot-Scale Testing of a SpinTek } \\
\text { Rotary Microfilter with SRS Simulated High Level Waste. } \\
\text { WSRC-TR-2004-00213, Pilot-Scale Testing of a SpinTek } \\
\text { Rotary Microfilter with Welded Disks and Simulated } \\
\text { Savannah River Site High Level Waste. }\end{array}$ \\
\hline
\end{tabular}




\begin{tabular}{|c|c|c|}
\hline $\mathbf{Y} / \mathbf{N}$ & $\begin{array}{l}\text { Criteria (only those related to "Technology, } \\
\text { technical aspects" in DOE G 413.3-4) }\end{array}$ & Basis and Supporting Documentation \\
\hline Y & $\begin{array}{l}\text { 14. Key process parameters/variables and } \\
\text { associated hazards have begun to be } \\
\text { identified; to include compliance with } \\
\text { DOE STD } 1189-2008 \text {, Integration of } \\
\text { Safety into the Design Process }\end{array}$ & $\begin{array}{l}\text { RPP-47251, Supplemental Treatment Pre-Conceptual } \\
\text { System Safety Design Strategy. }\end{array}$ \\
\hline Y & $\begin{array}{l}\text { 16. Paper studies indicate that system } \\
\text { components ought to work together }\end{array}$ & $\begin{array}{l}\text { RPP-46811, Functions and Requirements Analysis: } 200- \\
\text { Area Supplemental Treatment and Immobilization System. }\end{array}$ \\
\hline Y & $\begin{array}{l}\text { 18. Performance metrics for the system are } \\
\text { established (What must it do) }\end{array}$ & $\begin{array}{l}\text { RPP-46811, Functions and Requirements Analysis: } 200- \\
\text { Area Supplemental Treatment and Immobilization System. }\end{array}$ \\
\hline Y & 22. Scientific feasibility fully demonstrated & $\begin{array}{l}\text { WSRC-TR-2003-00071, Pilot-Scale Testing of a SpinTek } \\
\text { Rotary Microfilter with SRS Simulated High Level Waste. } \\
\text { WSRC-TR-2004-00213, Pilot-Scale Testing of a SpinTek } \\
\text { Rotary Microfilter with Welded Disks and Simulated } \\
\text { Savannah River Site High Level Waste. }\end{array}$ \\
\hline Y & $\begin{array}{l}\text { 23. Analysis of present state of the art shows } \\
\text { that technology fills a need }\end{array}$ & $\begin{array}{l}\text { RPP-PLAN-49827, Technology Maturation Plan for the } \\
\text { Treatment Project (T4S01). }\end{array}$ \\
\hline Y & $\begin{array}{l}\text { 27. Key physical and chemical properties have } \\
\text { been characterized for a number of waste } \\
\text { samples }\end{array}$ & $\begin{array}{l}\text { WSRC-TR-2000-00338, Hanford Waste Simulant created } \\
\text { to Support Research and Development on the River } \\
\text { Protection Project - Waste Treatment Plant. } \\
\text { WRPS-0802568, Report on SpinTek Rotary Microfilter } \\
\text { Feed Sample Comparison. } \\
\text { RPP-RPT-50764, Evaluation of AP-Farm Simulant } \\
\text { Composition for Rotary Microfilter Testing. }\end{array}$ \\
\hline Y & $\begin{array}{l}\text { 28. A simulant has been developed that } \\
\text { approximates key waste properties }\end{array}$ & $\begin{array}{l}\text { WSRC-TR-2000-00338, Hanford Waste Simulant created } \\
\text { to Support Research and Development on the River } \\
\text { Protection Project - Waste Treatment Plant. } \\
\text { RPP-RPT-50764, Evaluation of AP-Farm Simulant } \\
\text { Composition for Rotary Microfilter Testing. }\end{array}$ \\
\hline Y & $\begin{array}{l}\text { 29. Laboratory scale tests on a simulant have } \\
\text { been completed }\end{array}$ & $\begin{array}{l}\text { RPP-RPT-40897, Testing of the SpinTek Rotary } \\
\text { Microfilter using Simulated Hanford Waste Samples. } \\
\text { WSRC-STI-2008-00339, Testing of a Rotary Microfilter to } \\
\text { Support Hanford Applications. }\end{array}$ \\
\hline Y & $\begin{array}{l}\text { 30. Specific waste(s) and waste site(s) has } \\
\text { (have) been defined }\end{array}$ & $\begin{array}{l}\text { RPP-RPT-50024, Treatment Project T4S01 Conceptuatl } \\
\text { Design Report. }\end{array}$ \\
\hline Y & $\begin{array}{l}\text { 31. The individual system components have } \\
\text { been tested at the laboratory scale }\end{array}$ & $\begin{array}{l}\text { WSRC-TR-2003-00071, Pilot-Scale Testing of a SpinTek } \\
\text { Rotary Microfilter with SRS Simulated High Level Waste. } \\
\text { WSRC-TR-2004-00213, Pilot-Scale Testing of a SpinTek } \\
\text { Rotary Microfilter with Welded Disks and Simulated } \\
\text { Savannah River Site High Level Waste. } \\
\text { RPP-RPT-40897, Testing of the SpinTek Rotary } \\
\text { Microfilter using Simulated Hanford Waste Samples. }\end{array}$ \\
\hline
\end{tabular}

The Technology Readiness Level 4 is consistent with a definition of technology development. It is described in the DOE TRA Guide as, 
"Basic Technological components are integrated to establish that the pieces will work together. This is a relatively 'low fidelity' compared with the eventual system. Examples include integration of 'ad hoc' hardware in a laboratory and testing with a range of simulants."

All questions within the TRL 4 question set provided in Table 3, must be answered "yes' to be assigned a TRL 4 designation. The questions encompass technical, programmatic and manufacturing aspects of the evaluated critical technology element. Only technology aspects are shown.

Table 3. TRL 4 Question Set

\begin{tabular}{|c|c|c|}
\hline $\mathbf{Y} / \mathbf{N}$ & $\begin{array}{l}\text { Criteria (only those related to "Technology, } \\
\text { technical aspects" in DOE G 413.3-4) }\end{array}$ & Basis and Supporting Documentation \\
\hline Y & $\begin{array}{l}\text { 1. Key process variables/parameters been fully } \\
\text { identified and preliminary hazard evaluations have } \\
\text { been completed and documented; to include } \\
\text { compliance with DOE STD } 1189-2008 \text {, Integration } \\
\text { of Safety into the Design Process. }\end{array}$ & $\begin{array}{l}\text { RPP-46811, Functions and Requirements } \\
\text { Analysis: } 200-\text { Area Supplemental Treatment and } \\
\text { Immobilization System. } \\
\text { RPP-50169, Treatment Project T4S01 Conceptual } \\
\text { Safety Design Report. }\end{array}$ \\
\hline Y & $\begin{array}{l}\text { 3. Individual components tested in laboratory/ or } \\
\text { by supplier }\end{array}$ & $\begin{array}{l}\text { WSRC-STI-2008-00339, Testing of a Rotary } \\
\text { Microfilter to Support Hanford Applications. } \\
\text { Greene et al (1999), Centrifugal Membrane } \\
\text { Filtration Final Report, DE-AC21-96MC33136. }\end{array}$ \\
\hline Y & $\begin{array}{l}\text { 4. Subsystems composed of multiple components } \\
\text { tested at lab scale using simulants }\end{array}$ & $\begin{array}{l}\text { WSRC-STI-2008-00339, Testing of a Rotary } \\
\text { Microfilter to Support Hanford Applications. } \\
\text { RPP-RPT-40897, Testing of the SpinTek Rotary } \\
\text { Microfilter using Simulated Hanford Waste } \\
\text { Samples. }\end{array}$ \\
\hline Y & $\begin{array}{l}\text { 5. Modeling \& Simulation used to simulate some } \\
\text { components and interfaces between components }\end{array}$ & $\begin{array}{l}\text { Serra and Wiesner (2000), A Comparison of } \\
\text { Rotating and Stationary Membrane Disk Filters } \\
\text { using Computational Fluid Dynamics. }\end{array}$ \\
\hline Y & $\begin{array}{l}\text { 7. Overall system requirements for end user's } \\
\text { application are documented }\end{array}$ & $\begin{array}{l}\text { RPP-46811, Functions and Requirements } \\
\text { Analysis: } 200 \text {-Area Supplemental Treatment and } \\
\text { Immobilization System. }\end{array}$ \\
\hline Y & $\begin{array}{l}\text { 11. Laboratory experiments with available } \\
\text { components show that they work together }\end{array}$ & $\begin{array}{l}\text { WSRC-TR-2004-00213, Pilot-Scale Testing of a } \\
\text { SpinTek Rotary Microfilter with Welded Disks and } \\
\text { Simulated Savannah River Site High Level Waste. }\end{array}$ \\
\hline Y & $\begin{array}{l}\text { 12. Analysis completed to establish component } \\
\text { compatibility (Do components work together) }\end{array}$ & $\begin{array}{l}\text { WSRC-TR-2004-00213, Pilot-Scale Testing of a } \\
\text { SpinTek Rotary Microfilter with Welded Disks and } \\
\text { Simulated Savannah River Site High Level Waste. } \\
\text { RPP-RPT-40897, Testing of the SpinTek Rotary } \\
\text { Microfilter using Simulated Hanford Waste } \\
\text { Samples. }\end{array}$ \\
\hline
\end{tabular}




\begin{tabular}{|c|c|c|}
\hline $\mathbf{Y} / \mathbf{N}$ & $\begin{array}{l}\text { Criteria (only those related to "Technology, } \\
\text { technical aspects" in DOE G 413.3-4) }\end{array}$ & Basis and Supporting Documentation \\
\hline Y & $\begin{array}{l}\text { 14. Technology demonstrates basic functionality in } \\
\text { simulated environment; to include test and } \\
\text { validation of safety functions. }\end{array}$ & $\begin{array}{l}\text { WSRC-TR-2004-00213, Pilot-Scale Testing of a } \\
\text { SpinTek Rotary Microfilter with Welded Disks and } \\
\text { Simulated Savannah River Site High Level Waste. } \\
\text { RPP-RPT-40897, Testing of the SpinTek Rotary } \\
\text { Microfilter using Simulated Hanford Waste } \\
\text { Samples. }\end{array}$ \\
\hline Y & $\begin{array}{l}\text { 18. Controlled laboratory environment used in } \\
\text { testing }\end{array}$ & $\begin{array}{l}\text { RPP-RPT-40897, Testing of the SpinTek Rotary } \\
\text { Microfilter using Simulated Hanford Waste } \\
\text { Samples. }\end{array}$ \\
\hline Y & $\begin{array}{l}\text { 25. Functional process description developed. } \\
\text { (Systems/subsystems identified) }\end{array}$ & $\begin{array}{l}\text { RPP-46811, Functions and Requirements } \\
\text { Analysis: } 200 \text {-Area Supplemental Treatment and } \\
\text { Immobilization System. }\end{array}$ \\
\hline $\mathrm{Y}$ & $\begin{array}{l}\text { 26. Low fidelity technology "system" integration } \\
\text { and engineering completed in a lab environment }\end{array}$ & $\begin{array}{l}\text { WSRC-STI-2008-00339, Testing of a Rotary } \\
\text { Microfilter to Support Hanford Applications. }\end{array}$ \\
\hline Y & $\begin{array}{l}28 \text {. Key physical and chemical properties have } \\
\text { been characterized for a range of wastes }\end{array}$ & $\begin{array}{l}\text { WSRC-TR-2000-00338, Hanford Waste Simulant } \\
\text { created to Support Research and Development on } \\
\text { the River Protection Project - Waste Treatment } \\
\text { Plant. } \\
\text { WRPS-0802568, Report on SpinTek Rotary } \\
\text { Microfilter Feed Sample Comparison. } \\
\text { RPP-RPT-50764, Evaluation of AP-Farm } \\
\text { Simulant Composition for Rotary Microfilter } \\
\text { Testing. }\end{array}$ \\
\hline Y & $\begin{array}{l}\text { 29. A limited number of simulants have been } \\
\text { developed that approximate the range of waste } \\
\text { properties }\end{array}$ & $\begin{array}{l}\text { WSRC-TR-2000-00338, Hanford Waste Simulant } \\
\text { created to Support Research and Development on } \\
\text { the River Protection Project - Waste Treatment } \\
\text { Plant. } \\
\text { RPP-RPT-40897, Testing of the SpinTek Rotary } \\
\text { Microfilter using Simulated Hanford Waste } \\
\text { Samples. }\end{array}$ \\
\hline $\mathrm{Y}$ & $\begin{array}{l}\text { 30. Laboratory-scale tests on a limited range of } \\
\text { simulants and real waste have been completed }\end{array}$ & $\begin{array}{l}\text { RPP-RPT-40897, Testing of the SpinTek Rotary } \\
\text { Microfilter using Simulated Hanford Waste } \\
\text { Samples. } \\
\text { LAB-RPT-10-00002, Testing of the SpinTek } \\
\text { Rotary Microfilter using Actual Hanford Waste } \\
\text { Samples. }\end{array}$ \\
\hline $\mathrm{Y}$ & $\begin{array}{l}\text { 31. Process/parameter limits and safety control } \\
\text { strategies are being explored }\end{array}$ & $\begin{array}{l}\text { RPP-47251, Supplemental Treatment Pre- } \\
\text { Conceptual System Safety Design Strategy. } \\
\text { RPP-50359, Treatment Project T4S01 Safety } \\
\text { Design Strategy. }\end{array}$ \\
\hline $\mathrm{Y}$ & $\begin{array}{l}\text { 32. Test plan documents for prototypical lab- scale } \\
\text { tests completed }\end{array}$ & $\begin{array}{l}\text { RPP-PLAN-35933, Test Plan for Rotary } \\
\text { Microfilter Testing with Simulated and Actual } \\
\text { Tank Waste. }\end{array}$ \\
\hline
\end{tabular}


The Technology Readiness Level 5 is consistent with a definition of technology development. It is described in the DOE TRA Guide as,

"The basis technological components are integrated so that the system configuration is similar to (matches) the final application in almost all respects. Examples include testing a high-fidelity system in a simulated environment and/or with a range of real waste and simulants."

All questions within the TRL 5 question set provided in Table 4, must be answered "yes' to be assigned a TRL 5 designation. The questions encompass technical, programmatic and manufacturing aspects of the evaluated critical technology element. Only technology aspects are shown.

Table 4. TRL 5 Question Set

\begin{tabular}{|c|l|l|}
\hline Y/N & \multicolumn{1}{|c|}{$\begin{array}{c}\text { Criteria (only those related to "Technology, } \\
\text { technical aspects" in DOE G 413.3-4) }\end{array}$} & \multicolumn{1}{c|}{ Basis and Supporting Documentation } \\
\hline $\mathrm{Y}$ & $\begin{array}{l}\text { 1. The relationships between major system and sub- } \\
\text { system parameters are understood on a laboratory } \\
\text { scale. }\end{array}$ & $\begin{array}{l}\text { WSRC-STI-2006-00073, Testing and Evaluation } \\
\text { of the Modified Design of the 25-Disk Rotary } \\
\text { Microfilter. }\end{array}$ \\
\hline $\mathrm{Y}$ & $\begin{array}{l}\text { 2. Plant size components available for testing } \\
\text { Y }\end{array}$ & $\begin{array}{l}\text { WSRC-STI-2006-00073, Testing and Evaluation } \\
\text { of the Modified Design of the 25-Disk Rotary } \\
\text { Microfilter. }\end{array}$ \\
\hline $\mathrm{Y}$ & $\begin{array}{l}\text { 3ystem be integrated into the plant?) } \\
\text { established; to include testing and validation and } \\
\text { safety functions }\end{array}$ & $\begin{array}{l}\text { RPP-RPT-48117, Supplemental Treatment } \\
\text { Technical Support Pre-Conceptual Candidate } \\
\text { Technical Descriptions. } \\
\text { RPP-RPT-50024, Treatment Project T4S01 }\end{array}$ \\
\hline $\mathrm{Y}$ & $\begin{array}{l}\text { 6. Interfaces between components/subsystems in } \\
\text { testing are realistic (bench top with realistic } \\
\text { interfaces) }\end{array}$ & $\begin{array}{l}\text { WSRC-STI-2006-00073, Testing and Evaluation } \\
\text { of the Modified Design of the 25-Disk Rotary } \\
\text { Microfilter. }\end{array}$ \\
\hline $\mathrm{Y}$ & $\begin{array}{l}\text { 9. High fidelity lab integration of system completed, } \\
\text { ready for test in relevant environments; to include } \\
\text { testing and validation of safety functions }\end{array}$ & $\begin{array}{l}\text { WSRC-STI-2006-00073, Testing and Evaluation } \\
\text { of the Modified Design of the 25-Disk Rotary } \\
\text { Microfilter. }\end{array}$ \\
\hline $\mathrm{Y}$ & $\begin{array}{l}\text { 11. Lab-scale, similar system tested with range of } \\
\text { simulants }\end{array}$ & $\begin{array}{l}\text { WSRC-TR-2004-00047, Pilot Scale Testing of a } \\
\text { Rotary Microfilter with Irradiated Filter Disks } \\
\text { and Simulated SRS Waste. } \\
\text { RPP-RPT-40897, Testing of the SpinTek Rotary } \\
\text { Microfilter using Simulated Hanford Waste } \\
\text { Samples. }\end{array}$ \\
\hline & $\begin{array}{l}\text { WSRC-STI-2006-00073, Testing and Evaluation } \\
\text { of the Modified Design of the 25-Disk Rotary } \\
\text { Microfilter. }\end{array}$ \\
\hline
\end{tabular}




\begin{tabular}{|c|c|c|}
\hline $\mathbf{Y} / \mathbf{N}$ & $\begin{array}{c}\text { Criteria (only those related to "Technology, } \\
\text { technical aspects" in DOE G 413.3-4) } \\
\end{array}$ & Basis and Supporting Documentation \\
\hline Y & $\begin{array}{l}\text { 16. Laboratory environment for testing modified to } \\
\text { approximate operational environment; to include } \\
\text { testing and validation of safety functions }\end{array}$ & $\begin{array}{l}\text { WSRC-STI-2006-00073, Testing and Evaluation } \\
\text { of the Modified Design of the 25-Disk Rotary } \\
\text { Microfilter. }\end{array}$ \\
\hline Y & $\begin{array}{l}\text { 17. Component integration issues and requirements } \\
\text { identified }\end{array}$ & $\begin{array}{l}\text { WSRC-STI-2006-00073, Testing and Evaluation } \\
\text { of the Modified Design of the 25-Disk Rotary } \\
\text { Microfilter. }\end{array}$ \\
\hline Y & $\begin{array}{l}\text { 19. Requirements definition with performance } \\
\text { thresholds and objectives established for final plant } \\
\text { design }\end{array}$ & $\begin{array}{l}\text { RPP-46811, Functions and Requirements } \\
\text { Analysis: } 200 \text {-Area Supplemental Treatment and } \\
\text { Immobilization System. } \\
\text { RPP-RPT-50024, Treatment Project T4S01 } \\
\text { Conceptual Design Report. }\end{array}$ \\
\hline Y & $\begin{array}{l}\text { 21. Integration of modules/functions demonstrated in } \\
\text { a laboratory/bench-scale environment }\end{array}$ & $\begin{array}{l}\text { WSRC-STI-2006-00073, Testing and Evaluation } \\
\text { of the Modified Design of the 25-Disk Rotary } \\
\text { Microfilter. }\end{array}$ \\
\hline Y & $\begin{array}{l}\text { 22. Formal control of all components to be used in } \\
\text { final prototypical test system }\end{array}$ & $\begin{array}{l}\text { WSRC-STI-2006-00073, Testing and Evaluation } \\
\text { of the Modified Design of the 25-Disk Rotary } \\
\text { Microfilter. }\end{array}$ \\
\hline Y & $\begin{array}{l}24 \text {. The range of all relevant physical and chemical } \\
\text { properties has been determined (to the extent } \\
\text { possible) }\end{array}$ & $\begin{array}{l}\text { RPP-RPT-48117, Supplemental Treatment } \\
\text { Technical Support Pre-Conceptual Candidate } \\
\text { Technical Descriptions. } \\
\text { RPP-PLAN-49827, Technology Maturation Plan } \\
\text { for the Treatment Project (T4S01). } \\
\text { RPP-RPT-50764, Evaluation of AP-Farm } \\
\text { Simulant Composition for Rotary Microfilter } \\
\text { Testing. }\end{array}$ \\
\hline $\mathbf{N}$ & $\begin{array}{l}\text { 25. Simulants have been developed that cover the } \\
\text { full range of waste properties }\end{array}$ & $\begin{array}{l}\text { WSRC-TR-2000-00338, Hanford Waste } \\
\text { Simulant created to Support Research and } \\
\text { Development on the River Protection Project- } \\
\text { Waste Treatment Plant. } \\
\text { RPP-RPT-50764, Evaluation of AP-Farm } \\
\text { Simulant Composition for Rotary Microfilter } \\
\text { Testing. } \\
\text { Task RMF-4 in RPP-PLAN-49827, Technology } \\
\text { Maturation Plan for the Treatment Project } \\
\text { (T4SO1). }\end{array}$ \\
\hline
\end{tabular}




\begin{tabular}{|c|c|c|}
\hline $\mathbf{Y} / \mathbf{N}$ & $\begin{array}{l}\text { Criteria (only those related to "Technology, } \\
\text { technical aspects" in DOE G 413.3-4) }\end{array}$ & Basis and Supporting Documentation \\
\hline $\mathbf{N}$ & $\begin{array}{l}\text { 26. Testing has verified that the } \\
\text { properties/performance of the simulants match } \\
\text { the properties/performance of the actual wastes }\end{array}$ & $\begin{array}{l}\text { WSRC-TR-2004-00213, Pilot-Scale Testing of a } \\
\text { SpinTek Rotary Microfilter with Welded Disks } \\
\text { and Simulated Savannah River Site High Level } \\
\text { Waste. } \\
\text { WSRC-TR-2003-00030, Testing of the SpinTek } \\
\text { Rotary Microfilter using Actual Waste. } \\
\text { WRPS-0802568, Report on SpinTek Rotary } \\
\text { Microfilter Feed Sample Comparison. } \\
\text { LAB-RPT-10-00002, Testing of the SpinTek } \\
\text { Rotary Microfilter using Actual Hanford Waste } \\
\text { Samples. } \\
\text { Task RMF-10 in RPP-PLAN-49827, Technology } \\
\text { Maturation Plan for the Treatment Project } \\
\text { (T4S01). }\end{array}$ \\
\hline $\mathbf{N}$ & $\begin{array}{l}\text { 27. Laboratory-scale tests on the full range of } \\
\text { simulants using a prototypical system have been } \\
\text { completed }\end{array}$ & $\begin{array}{l}\text { WSRC-STI-2008-00339, Testing of a Rotary } \\
\text { Microfilter to Support Hanford Applications. } \\
\text { RPP-RPT-40897, Testing of the SpinTek Rotary } \\
\text { Microfilter using Simulated Hanford Waste } \\
\text { Samples. } \\
\text { Task RMF-2 in RPP-PLAN-49827, Technology } \\
\text { Maturation Plan for the Treatment Project } \\
\text { (T4S01). } \\
\text { Task RMF-5a in RPP-PLAN-49827, Technology } \\
\text { Maturation Plan for the Treatment Project } \\
\text { (T4S01). }\end{array}$ \\
\hline $\mathbf{N}$ & $\begin{array}{l}\text { 28. Laboratory-scale tests on a limited range of } \\
\text { real wastes using a prototypical system have been } \\
\text { completed }\end{array}$ & $\begin{array}{l}\text { LAB-RPT-10-00002, Testing of the SpinTek } \\
\text { Rotary Microfilter using Actual Hanford Waste } \\
\text { Samples. } \\
\text { Task RMF-10 in RPP-PLAN-49827, Technology } \\
\text { Maturation Plan for the Treatment Project } \\
(\text { T4SO1). }\end{array}$ \\
\hline $\mathbf{N}$ & $\begin{array}{l}\text { 29. Test results for simulants and real waste are } \\
\text { consistent }\end{array}$ & $\begin{array}{l}\text { WSRC-TR-2003-00030, Testing of the Spintek } \\
\text { Rotary Microfilter using Actual Waste. } \\
\text { LAB-RPT-10-00002, Testing of the SpinTek } \\
\text { Rotary Microfilter using Actual Hanford Waste } \\
\text { Samples. } \\
\text { Task RMF-10 in RPP-PLAN-49827, Technology } \\
\text { Maturation Plan for the Treatment Project } \\
\text { (T4SO1). }\end{array}$ \\
\hline Y & $\begin{array}{l}\text { 30. Laboratory to engineering scale scale-up issues } \\
\text { are understood and resolved }\end{array}$ & $\begin{array}{l}\text { WSRC-STI-2006-00073, Testing and Evaluation } \\
\text { of the Modified Design of the 25-Disk Rotary } \\
\text { Microfilter. } \\
\text { SRNL-STI-2011-00466, Testing of the Dual } \\
\text { Rotary Filter System. }\end{array}$ \\
\hline
\end{tabular}




\begin{tabular}{|c|c|c|}
\hline $\mathbf{Y} / \mathbf{N}$ & $\begin{array}{l}\text { Criteria (only those related to "Technology, } \\
\text { technical aspects" in DOE G 413.3-4) }\end{array}$ & Basis and Supporting Documentation \\
\hline Y & $\begin{array}{l}\text { 31. Limits for all process variables/parameters and } \\
\text { safety controls are being refined }\end{array}$ & $\begin{array}{l}\text { RPP-50169, Treatment Project T4S01 } \\
\text { Conceptual Safety Design Report. } \\
\text { RPP-50359, Treatment Project T4S01 Safety } \\
\text { Design Strategy. }\end{array}$ \\
\hline
\end{tabular}

The Technology Readiness Level 6 is consistent with a definition of technology demonstration. It is described in the DOE TRA Guide as,

"Representative engineering scale model or prototype system, which is well beyond the lab scale tested for TRL 5, is tested in a relevant environment. Represents a major step up in a technology's demonstrated readiness. Examples include testing a prototype with real waste and a range of simulants."

All questions within the TRL 6 question set provided in Table 5, must be answered "yes' to be assigned a TRL 6 designation. The questions encompass technical, programmatic and manufacturing aspects of the evaluated critical technology element. Only the technology aspects are shown.

Table 5. TRL 6 Question Set

\begin{tabular}{|c|l|l|}
\hline Y/N & \multicolumn{1}{|c|}{$\begin{array}{c}\text { Criteria (only those related to “Technology, } \\
\text { technical aspects" in DOE G 413.3-4) }\end{array}$} & \multicolumn{1}{c|}{ Basis and Supporting Documentation } \\
\hline Y & $\begin{array}{l}\text { 1. The relationships between system and sub-system } \\
\text { parameters are understood at engineering scale } \\
\text { allowing process/design variations and tradeoffs to be } \\
\text { evaluated. }\end{array}$ & $\begin{array}{l}\text { RPP-46811, Functions and Requirements } \\
\text { Analysis: 200-Area Supplemental Treatment } \\
\text { and Immobilization System. } \\
\text { RPP-RPT-50024, Treatment Project T4S01 } \\
\text { Conceptual Design Report. }\end{array}$ \\
\hline $\mathrm{Y}$ & 4. Operating environment for final system known & $\begin{array}{l}\text { RPP-RPT-50024, Treatment Project T4S01 } \\
\text { Conceptual Design Report. }\end{array}$ \\
\hline $\mathrm{Y}$ & $\begin{array}{l}\text { 7. Operating limits for components determined (from } \\
\text { design, safety and environmental compliance) }\end{array}$ & $\begin{array}{l}\text { RPP-RPT-50024, Treatment Project T4S01 } \\
\text { Conceptual Design Report. }\end{array}$ \\
\hline $\mathrm{Y}$ & $\begin{array}{l}\text { 10. System technical interfaces defined } \\
\text { Y }\end{array}$ & $\begin{array}{l}\text { RPP-46811, Functions and Requirements } \\
\text { Analysis: 200-Area Supplemental Treatment } \\
\text { and Immobilization System. }\end{array}$ \\
\hline $\mathrm{Y}$ & $\begin{array}{l}\text { 11. Component integration demonstrated at an } \\
\text { engineering scale }\end{array}$ & $\begin{array}{l}\text { SRNL-STI-2009-00183, Testing of a full-scale } \\
\text { Rotary Microfilter for the Enhanced Process for } \\
\text { Radionuclides Removal. } \\
\text { SRNL-STI-2011-00466, Testing of the Dual } \\
\text { Rould it work) }\end{array}$ \\
\hline
\end{tabular}




\begin{tabular}{|c|c|c|}
\hline $\mathbf{Y} / \mathbf{N}$ & $\begin{array}{l}\text { Criteria (only those related to "Technology, } \\
\text { technical aspects" in DOE G 413.3-4) }\end{array}$ & Basis and Supporting Documentation \\
\hline $\mathrm{Y}$ & $\begin{array}{l}\text { 22. Engineering-scale system is high-fidelity } \\
\text { functional prototype of operational system }\end{array}$ & $\begin{array}{l}\text { SRNL-STI-2009-00183, Testing of a full-scale } \\
\text { Rotary Microfilter for the Enhanced Process for } \\
\text { Radionuclides Removal. } \\
\text { SRNL-STI-2011-00466, Testing of the Dual } \\
\text { Rotary Filter System. }\end{array}$ \\
\hline $\mathbf{N}$ & $\begin{array}{l}\text { 28. Engineering-scale tests on the full range of } \\
\text { simulants using a prototypical system have been } \\
\text { completed }\end{array}$ & $\begin{array}{l}\text { WSRC-STI-2008-00339, Testing of a Rotary } \\
\text { Microfilter to Support Hanford Applications. } \\
\text { Task RMF-5a in RPP-PLAN-49827, } \\
\text { Technology Maturation Plan for the Treatment } \\
\text { Project (T4S01). }\end{array}$ \\
\hline Y & $\begin{array}{l}\text { 29. Engineering to full-scale scale-up issues are } \\
\text { understood and resolved }\end{array}$ & $\begin{array}{l}\text { SRNL-STI-2009-00183, Testing of a full-scale } \\
\text { Rotary Microfilter for the Enhanced Process for } \\
\text { Radionuclides Removal. } \\
\text { SRNL-STI-2011-00466, Testing of the Dual } \\
\text { Rotary Filter System. }\end{array}$ \\
\hline $\mathbf{N}$ & $\begin{array}{l}\text { 30. Laboratory and engineering-scale experiments } \\
\text { are consistent }\end{array}$ & $\begin{array}{l}\text { WSRC-STI-2008-00339, Testing of a Rotary } \\
\text { Microfilter to Support Hanford Applications. } \\
\text { RPP-RPT-40897, Testing of the SpinTek Rotary } \\
\text { Microfilter using Simulated Hanford Waste } \\
\text { Samples. } \\
\text { Task RMF-1 \& } 2 \text { in RPP-PLAN-49827, } \\
\text { Technology Maturation Plan for the Treatment } \\
\text { Project (T4S01). }\end{array}$ \\
\hline $\mathrm{Y}$ & $\begin{array}{l}\text { 31. Limits for all process variables/parameters and } \\
\text { safety controls are defined }\end{array}$ & $\begin{array}{l}\text { RPP-RPT-50024, Treatment Project T4SO1 } \\
\text { Conceptual Design Report. }\end{array}$ \\
\hline $\mathbf{N}$ & $\begin{array}{l}\text { 32. Plan for engineering-scale testing executed - } \\
\text { results validate design }\end{array}$ & $\begin{array}{l}\text { WSRC-STI-2008-00339, Testing of a Rotary } \\
\text { Microfilter to Support Hanford Applications. } \\
\text { Task RMF-5a in RPP-PLAN-49827, } \\
\text { Technology Maturation Plan for the Treatment } \\
\text { Project (T4S01). } \\
\text { SRNL-STI-2011-00466, Testing of the Dual } \\
\text { Rotary Filter System. }\end{array}$ \\
\hline
\end{tabular}

